\title{
Effects of Long Acting Methylphenidate on Ghrelin Levels in Male Children with Attention Deficit Hyperactivity Disorder: An Open Label Trial
}

\author{
Ozhan Yalcin', Elvan Iseri², Neslihan Bukan³, Ugur Ercin ${ }^{3}$
}

ÖZET:

Dikkat eksikliği hiperaktivite bozukluğu olan erkek çocuklarında uzun etkili metilfenidatın ghrelin düzeylerine olan etkisi: Açık uçlu bir çalışma

Amaç: Dikkat eksikliği hiperaktivite bozukluğu için sıklıkla kullanılan metilfenidatın en sık görülen yan etkileri iştah kaybı, vücut ağırlığında azalma ve başlangıçta olan büyüme geriliğidir. Baskın olarak mideden salınan ghrelin beslenme davranışını arttırır, enerji tüketimini ve lokomotor aktiviteyi azaltır, kilo alımı ve yağ depolanmasını arttıır ve ayrıca gastrointestinal motiliteyi etkiler. Ghrelin metilfenidatın çocuklar üzerindeki metabolik ve anoreksijenik etkileri ile ilişkili olabilir. Bu çalışmanın amacı metilfenidatın ergenlik dönemi öncesi dikkat eksikliği hiperaktivite bozukluğu olan çocuklarda açlık serum aktif ghrelin düzeyleri üzerine olan etkisini araştırmaktır. Ergenlik öncesi erkek çocuklarında ağızdan alınan ozmotik kontrollü salınımı olan $18 \mathrm{mg} /$ gün metilfenidat ile tedavi öncesi ve sonrası ghrelin düzeylerinde değişiklik saptamayı bekledik.

Yöntem: Dikkat eksikliği hiperaktivite bozukluğu olan 6-12 yaş arasındaki otuz üç erkek çocuğu çalışmaya alındı. 60 günlük metilfenidat tedavisi öncesi ve sonrasındaki ghrelin düzeyleri dışında, diğer laboratuar bulguları, beden-kitle indeksi, beden-kitle indeksi persentilleri, boy, vücut ağırlığı ve dikkat eksikliği hiperaktivite bozukluğu semptom şiddeti ölçümleri de analize alındı.

Bulgular: Metilfenidat tedavisi ile serum aktif ghrelin düzeylerinde bir farklıık saptanmadı. Metilfenidat boy, vücut ağırlığı ve beden kitle indeksi üzerinde önemli bir değişiklik yapmadan ve ciddi bir yan etki oluşturmadan dikkat eksikliği hiperaktivite bozukluğunun dikkat bozukluğu, hiperaktivite, dürtüsellik temel bulgularında iyileşme sağlamıştır.

Tartışma: Bu çalışma metilfenidatın serum aktif ghrelin düzeyleri üzerine olan etkisini belirlemeye yönelik ilk çalışmadır. Dikkat eksikliği hiperaktivite bozukluğu ile yakından bağlantılı obezite, alkol ve madde bağımlılığı, ödül sistemi bozukluklarının ghrelinle ilişkisi nedeniyle daha yüksek metilfenidat dozlarıyla ya da atomoksetin ve amfetamin gibi stimulanlarla da ileri araştırmalar yapılmalıdır.

Anahtar sözcükler: dikkat eksikliği hiperaktivite bozukluğu, ghrelin, metilfenidat, psikostimülanlar

Klinik Psikofarmakoloji Bulteni 2014;24(2):146-57
ABSTRACT:

Effects of long acting methylphenidate on ghrelin levels in male children with attention deficit hyperactivity disorder: an open label trial

Objective: The most commonly reported side effects of methylphenidate, which is generally used for attention deficithyperactivity disorder, are loss of appetite, decrease of body weight and initial growth retardation. Ghrelin, which is dominantly released by the stomach, promotes feeding, decreases energy expenditure and locomotor activity, enhances weight gain and fat mass deposition and also effects gastrointestinal motility. Ghrelin may be related to the metabolic and anorexigenic effects of methylphenidate in children. The aim of this study was to investigate methylphenidate's effect on fasting serum active ghrelin levels in prepubertal children with attention deficit hyperactivity disorder. We expected to find a difference between pre- and post-treatment ghrelin levels with $18 \mathrm{mg} /$ day methylphenidate administered via an osmotic-controlled release oral delivery system in prepubertal boys.

Methods: Thirty-three boys with attention deficit hyperactivity disorder between the ages of 6-12 were recruited for this investigation. In addition to ghrelin levels, other laboratory findings, body mass index, body mass index percentiles, body weight-height measures and attention deficit-hyperactivity disorder symptom severity findings were analyzed before and after the 60 days of methylphenidate treatment.

Results: We could not find a significant alteration in serum active ghrelin levels with methylphenidate. Methylphenidate improved core inattention, hyperactivity and impulsivity symptoms of attention deficit hyperactivity disorder with no significant alteration in height, body weight and body mass index, without serious side effects.

Conclusion: This is the first study which directly aims to determine methylphenidate's effect on serum active ghrelin levels. Further research with higher methylphenidate doses and/or other stimulants such as atomoxetine and amphetamine should be done as ghrelin is also associated with obesity, alcohol and drug addiction and reward system pathologies, which are also closely related to attention deficit hyperactivity disorder.

Keywords: attention deficit hyperactivity disorder, ghrelin, methylphenidate, psychostimulants

Bulletin of Clinical Psychopharmacology 2014;24(2):146-57
'M.D., Bakirkoy Training and Research Hospital for Mental Disorders and Neurological Diseases, Istanbul - Turkey ${ }^{2}$ M.D., Gazi University School of Medicine, Department of Child and Adolescent Psychiatry, Ankara - Turkey ${ }^{3}$ M.D. . Gazi University School of Medicine, Department of Medical Biochemistry, Ankara - Turkey

Address reprint requests to: Dr. Özhan Yalçın

Bakırköy Ruh ve Sinir Hastalıklar Eğitim ve Arastırma Hastanesi İstanbul - Türkiye

Phone: +90-532-523-1550

E-mail address: cpozhan@gmail.com

Date of submission: May 10, 2013

Date of acceptance: July 8,2013

Declaration of interest:

O.Y., E.I., N.B., U.E.: The authors reported no conflict of interest related to this article. 


\section{INTRODUCTION}

Stimulant medications are the most widely used medical agents for the treatment of Attention Deficit / Hyperactivity Disorder (ADHD) and have been shown in many studies to significantly reduce the symptoms of inattention, hyperactivity and impulsivity that characterize this disorder. Methylphenidate is the most common stimulant prescribed for managing ADHD symptoms ${ }^{1}$. Methylphenidate inhibits dopamine transporter and norepinephrine reuptake $\mathrm{e}^{1,2}$. The most common short-term adverse effects associated with methylphenidate in school age children are appetite loss and sleep problems ${ }^{3}$. It has been suggested that methylphenidate treatment might slow the rate of growth in height by compromising weight gain over several years. Despite numerous studies published over three decades on growth in children on stimulants, this remains a controversial issue $\mathrm{e}^{4,5}$.

With respect to the anorectic effects of psychostimulants, the role of Neuropeptide Y (NPY), a potent stimulant of appetite, is being considered as a possible mechanism. Psychostimulants decrease hypothalamic NPY levels. It has been reported that the level of hypothalamic NPY markedly decreases on the first day of stimulant administration but then quickly returns to normal ${ }^{6}$. Indeed Spencer investigated whether prolonged therapy with a long acting stimulant affects growth in children with ADHD. It was found that the effects of prolonged OROS-methylphenidate (OROS: Osmotic-controlled Release Oral delivery System) therapy on growth were clinically insignificant and limited to slight decreases in weight only during the first months of the therapy?

Ghrelin was identified as an endogenous ligand for the growth hormone secretagogue receptor (GHS-R) type $1 \mathrm{a}^{8}$. Ghrelinisproduced predominantly by the stomach but also by many other tissues (hypothalamus, pituitary, intestine) ${ }^{9}$. Ghrelin has a wide spectrum of biological activities beyond the stimulation of growth hormone release. Ghrelin stimulates appetite and food intake and decreases energy expenditure and locomotor activity, enhancing weight gain and fat mass deposition and also effects gastrointestinal motility ${ }^{10-14}$. Ghrelin is the only known circulating hormone that promotes feeding. Ghrelin levels increase during fasting and before the onset of meals and decrease strongly 30 minutes after feeding, suggesting that ghrelin levels might serve as a signal for meal initiation ${ }^{15}$. Plasma ghrelin levels are negatively correlated with Body Mass Index (BMI) ${ }^{16}$.

Ghrelin stimulates appetite by acting on the hypothalamic arcuate nucleus. In this area, ghrelin stimulates the activity of neurons expressing NPY and Agouti-Related Protein (AGRP) which stimulate appetite and inhibits (with the increase of $\gamma$-aminobutyric acid-GABA) the activity of neurons expressing Pro-Opiomelano-Cortin (POMC), the precursor to $\alpha$-melanocyte- stimulating hormone $(\alpha-\mathrm{MSH})$ and melanocortin as well as Cocaine-and Amphetamine Regulated Transcript (CART) $)^{9,13,17,18}$.

Ghrelin has direct effects on the central nervous system and is involved in many behavioral, neuroendocrinal, cognitive and neuropsychological processes. Ghrelin may also exert developmental and organizational effects during perinatal life like blastocyst development, perinatal growth and neurogenesis ${ }^{14}$. In addition, ghrelin has neuroprotective effects such as promoting and protecting nigrostriatal dopamine function via mitochondrial mechanisms ${ }^{19}$.

Ghrelin has been associated with many psychiatric symptoms and psychiatric diseases as well as psychotropic drug effects and side effects $^{14,16,20-22}$. For example, atypical antipsychotics are generally associated with significant weight gain. It has been claimed that when the antipsychotic treatment is brief (2-9 weeks) there is a decrease in serum active ghrelin levels and there is an increase in longer duration (26-52 weeks) of atypical antipsychotic treatment ${ }^{23,24}$. Plasma ghrelin level is increased in anorexia nervosa and cachexia ${ }^{16}$ and decreased in weight gain due to overfeeding, obesity $^{16,25}$, pregnancy ${ }^{26}$, olanzapine and risperidone (atypical antipsychotics) treatment ${ }^{20,21}$. But conversely, risperidone which is also used in ADHD treatment has been found in one study to be directly related to weight gain due to ghrelin increase ${ }^{22}$.

Ghrelin gene (GHRL) polymorphisms have been 
associated with greater BMI increase during atypical antipsychotic treatment in schizophrenia ${ }^{27}$. Ghrelin gene (GHRL) polymorphisms have been also associated with higher plasma lipid and glucose levels, higher blood pressure and greater $\mathrm{BMI}^{27}$ Ghrelin antagonists may play a crucial role in obesity treatment and may suppress the motivation for consumption of sucrose and sweet foods ${ }^{28}$.

Ghrelin is also involved in more complex cognitive-behavioral processes like learning, memory, reward, addiction and depressive and anxious symptoms ${ }^{14,29}$. In addition, it has been suggested that ghrelin (by a mechanism similar to compensatory increase to food restriction) could be important in drug, stimulant and alcohol abuseaddiction mechanisms ${ }^{30-33}$. As a result, it is important to design studies to investigate possible interactions between methylphenidate and ghrelin because ADHD increases the risk of drug and alcohol abuse. The most important aim of this study was to determine the relationship between methylphenidate's influence on appetite, weight, BMI, BMI percentiles and serum biologically active ghrelin levels in children with ADHD. Our hypothesis was that an increase in ghrelin levels due to methylphenidate was related to appetite or body weight loss. However, if methylphenidate related appetite decrease is associated with ghrelin, we may find the decreasinglevels of ghrelin. To our knowledge based on a search of the scientific literature, this is the first research which directly aims to observe methylphenidate's effect on ghrelin levels.

\section{METHODS}

\section{Subjects}

Participants were 40 prepubertal boys, 6-12 years of age, who were recruited from the Child and Adolescent Psychiatry Department of Gazi University Hospital in Ankara. The original trial began in December 2007 and finished in December 2008. Before starting the trial, application to the Gazi University Medical Faculty, Ethics Committee had been submitted, as a phase 4 clinical study. The Ethics Committee of Gazi University Medical
Faculty approved the study (reference number, 2007-4708-217). Only volunteers were recruited to the study. All the participants and their parents were informed and a written informed consent was obtained from parents. This study was performed in accordance with the ethical standards announced in the Declaration of Helsinki of 1964.

Inclusion criteria were: 1 ) being a prepubertal male child, 2) meeting the DSM-IV criteria for ADHD, 3) no usage of methylphenidate or any other psychiatric drug treatment before the trial, 4) having no depression or psychotic disorder at the time of the trial, 5) no history of autism, mental retardation, developmental delay, any other neurological, endocrinological, metabolic or infectious disease or cardiac, liver or kidney dysfunction and no routine use of any drugs.

As the different endocrinological and metabolic profile of female patients could change and complicate the final findings of this research, we decided not to include female patients.

\section{Procedures and assessment measures}

The versions adapted for the Turkish population of the Conners' Teacher Rating Scale (CTRS-28) ${ }^{34,35}$, the Conners' Parent Rating Scale (CPRS-48) ${ }^{34,36}$ and the Conners' parent-teacher rating scales-revised ${ }^{37,38}$ were used to collect multiple sources of information or behavioral symptoms of attention deficit and disruptive behaviors of ADHD. For the confirmation of the ADHD diagnosis and to determine the ADHD subtype and the diagnosis of other earlier and present psychiatric disorders and to exclude depression and psychosis, the Turkish version of the Schedule for Affective Disorders and Schizophrenia for School Age Children-Present and Lifetime Version (K-SADS-PL) was used ${ }^{39,40}$. For determination and exclusion of mental retardation the Wechsler Intelligence Scale for Children-Revised (WISC-R) ${ }^{41,42}$ was used. The K-SADS-PL was rated by the same child psychiatrist and the WISC-R was performed by the same clinical psychologist for all the participants.

ADHD severity was assessed initially and 60 days after treatment by using the CPRS-48 and CTRS-28. OROS-methylphenidate treatment in a total daily 
dose of $18 \mathrm{mg}$ was administered to the children with ADHD. Weekend drug holidays were not advised. As dose titration is more problematic with OROSmethylphenidate than immediate release methylphenidate on a per kilogram basis, we decided to use a fixed dose of $18 \mathrm{mg}$ OROSmethylphenidate rather than a flexible dose. To determine the effect of methylphenidate, ghrelin, glucose, biochemical values (aspartate transaminase, alanine transaminase, $\gamma$-glutamyltransferase, lactate dehydrogenase, total bilirubin, direct bilirubin, free T3, free T4, thyroidstimulating hormone, total protein, albumin), psychometric values, weight, height BMI and BMI percentile values were analyzed before and 60 days after treatment. Blood samples were taken after 12 hours fasting in the morning.

To determine the side effects of OROSmethylphenidate, the mothers completed a questionnaire by rating the severity of methylphenidate associated adverse reactions (sleep problems, headache, tics, loss of appetite, abdominal pain, weight loss, sadness, mouth dryness, nausea, vomiting, fears, irritability, skin eruption and others): 0 , not a problem; 1 , mild; 2,moderate; 3 ,severe. Before and after medication, appetite status of the children was also rated similarly by the mothers.

Standard calibrated scales were used to determine height and weight. Weight and height were measured to the nearest $0.1 \mathrm{~kg}$. and $0.1 \mathrm{~cm}$., respectively, according to a National Institutes of Health Protocol. BMI was calculated by dividing weight (in kilograms) by the squared height (in meters) $\left(\mathrm{kg} / \mathrm{m}^{2}\right)$. BMI percentiles were determined by the Turkish children standardization charts ${ }^{43}$.
The patients were instructed not to change diet or physical activity during the study.

\section{Laboratory Methods}

Serum biologically active ghrelin levels were measured by using an Enzyme Immune Assay Kit (Ghrelin Acylated Cayman/96 Test/EIA kit material), which is designed to detect a specific peptide and its related peptides, based on the principle of “competitive" enzyme immunoassay (Phoenix Pharmaceuticals Inc. USA). The minimum detectable concentration of ghrelin was $0.1 \mathrm{ng} / \mathrm{ml}$ for this assay technique (44).

\section{Statistics}

Statistical analyzes were calculated with SPSS 11.5 Statistics software. A nonparametric test, Wilcoxon's ranked-sums test for paired samples was used for the interpretation of laboratory findings and ADHD rating scales. The Spearman test was used for correlation analysis.

\section{RESULTS}

Two patients dropped out of the study in the course of follow up. Five patients were excluded as they used another drug for medical conditions in the trial period. Analyses were carried out on 33 boys. Age range of the participants was between 7 and 12 (mean 9.20 \pm 1.35 ). According to K-SADS-PL, the participants had $27.27 \%$ (n:9) predominately inattentive, $18.18 \%$ (n:6) predominatelyhyperactiveimpulsive, $54.54 \%$ (n:18) combined subtype of ADHD. Comorbid diagnoses were: $36.36 \%$ (n:12)

Table 1: Pre- and Post-treatment Conners rating scale scores

\begin{tabular}{lccc} 
& $\begin{array}{c}\text { Pretreatment } \\
\mathbf{n : 3 3}\end{array}$ & $\begin{array}{c}\text { Post-treatment } \\
\mathbf{n : 3 3}\end{array}$ & $\mathbf{p}^{\mathbf{a}}$ \\
\hline CTRS-AD & $15.40 \pm 4.42$ & $11.27 \pm 3.84$ & 0.001 \\
CTRS-HA & $10.54 \pm 3.41$ & $9.09 \pm 2.64$ & 0.003 \\
CTRS-CD & $7.54 \pm 3.80$ & $4.86 \pm 2.64$ & 0.001 \\
CPRS-AD & $7.50 \pm 2.24$ & $5.13 \pm 2.60$ & 0.001 \\
CPRS-HA & $7.95 \pm 2.83$ & $5.54 \pm 2.17$ & 0.001 \\
CPRS-CD & $10.50 \pm 6.71$ & $7.86 \pm 5.70$ & $<0.001$ \\
CPRS-OD & $7.04 \pm 3.12$ & $4.95 \pm 3.25$ & 0.001 \\
\hline
\end{tabular}

CPRS-: Conners Parent Rating Scale- (AD: attention deficit, HA: hyperactivity-impulsivity, CD: conduct disorder, OD: oppositional defiant), CTRS: Conners Teacher Rating scale, aWilcoxon's ranked-sums test was used for comparison between pretreatment and post-treatment values of ADHD group. 
Table 3: Height, Weight, BMI, BMI percentiles and ghrelin values of the subjects (pre- and post treatment)

\begin{tabular}{|c|c|c|c|c|c|}
\hline & Height (cm) & Weight (kg) & BMI $\left(\mathbf{k g} / \mathrm{m}^{2}\right)$ & BMI percentiles (\%) & Ghrelin (ng/ml) \\
\hline Pretreat n:33 & $134.59 \pm 12.32$ & $33.11 \pm 10.00$ & $17.99 \pm 2.76$ & $66.81 \pm 24.51$ & $40.83 \pm 0.39$ \\
\hline Post treat $\mathrm{n}: 33$ & $135.95 \pm 12.473$ & $33.43 \pm 10.26$ & $17.77 \pm 2.71$ & $64.40 \pm 27.53$ & $40.46 \pm 1.43$ \\
\hline $25^{\text {th }}$ percentile & & & & & \\
\hline $\begin{array}{l}\text { pre/post treat } \\
50^{\text {th }} \text { percentile }\end{array}$ & $125.75 / 127.75$ & $27.00 / 26.75$ & $16.19 / 15.66$ & $51.75 / 43.25$ & $40.78 / 40.47$ \\
\hline $\begin{array}{l}\text { pre/posttreat (median) } \\
75^{\text {th }} \text { percentile }\end{array}$ & $131.00 / 132.50$ & $29.50 / 30.00$ & $17.42 / 17.27$ & $72.00 / 68.00$ & $40.97 / 40.95$ \\
\hline pre/post treat & $141.25 / 143.00$ & $38.25 / 39.12$ & $18.48 / 18.22$ & $89.25 / 90.25$ & $41.08 / 41.04$ \\
\hline Z & -4.038 & -1.353 & -1.550 & -0.666 & -0.539 \\
\hline$p^{a}$ & $<0.001$ & 0.176 & 0.121 & 0.506 & 0.590 \\
\hline
\end{tabular}

'Wilcoxon's ranked-sums test was used for comparison between pretreatment and posttreatment values of ADHD group. pre/post treat:. pretreatment and post-treatment

Table 3: Statistical correlation values between the difference in ghrelin's serum level and variation of the Conners rating scales subpoints after two months of methylphenidate treatment

\begin{tabular}{llllllll} 
& ctrs-ad & ctrs-ha & ctrs-cd & cprs-ad & cprs-ha & cprs-cd & cprs-od \\
\hline ghrelin variation $(\mathrm{ng} / \mathrm{ml})$ & $\mathrm{p}=0.533$ & $\mathrm{p}=0.490$ & $\mathrm{p}=0.884$ & $\mathrm{p}=0.407$ & $\mathrm{p}=0.683$ & $\mathrm{p}=0.080$ & $\mathrm{p}=0.264$ \\
& $\mathrm{r}=0.140$ & $\mathrm{r}=-0.155$ & $\mathrm{r}=-0.033$ & $\mathrm{r}=0.186$ & $\mathrm{r}=0.092$ & $\mathrm{r}=0.381$ & $\mathrm{r}=0.249$ \\
\hline
\end{tabular}

Spearman test was used for correlation between pretreatment and post-treatment values of ADHD group, cprs-: Conners Parent Rating Scale- (ad: attention deficit,

ha: hyperactivity-impulsivity, cd: conduct disorder, od: oppositional defiant); ctrs: Conners Teacher Rating scale

oppositional defiant disorder, $9.09 \%$ (n:3) enuresis nocturna , $6.06 \%(\mathrm{n}: 2)$ enuresis diurna or encopresis.

There were statistically significant improvements in the symptoms of ADHD according to CPRS-48 and CTRS-28 (Table 1).

According to our findings, the body weight of 10 (30.30\%) cases did not change, 15 (45.45\%) had increased and 8 (24.24\%) had decreased body weight. The height of 30 cases $(90.90 \%)$ of the subjects increased. BMI increased in $14(42.42 \%)$ of the participants increased and decreased in 15 (45.45\%). In 4 (12.12\%) of the subjects, BMI did not change.

Only in height was there a statistically significant $(\mathrm{z}=-0.438, \mathrm{p}<0.001)$ increase. We didn't observe statistically meaningful alterations in weight $(\mathrm{z}=$ 1.353, $\mathrm{p}=0.176)$, BMI $(\mathrm{z}=-1.550, \mathrm{p}=0.121)$ or BMI percentiles $(\mathrm{z}=-0.666, \mathrm{p}=0.506)$ (Table 2$)$.

After the treatment, 5 (15.15\%) of the sample did not have any appetite decrease, 15 (45.45\%) participants had mild, 11 (33.30\%) participants had moderate and $2(6.06 \%)$ participants had severe appetite decrease.

Mean active serum ghrelin level before the treatment was $40.83( \pm 0.39) \mathrm{ng} / \mathrm{ml}$ and $40.46( \pm 1.43)$ $\mathrm{ng} / \mathrm{ml}$ after the treatment. There was no statistically significant difference (z:-0.539, p:0.590) between pretreatment and post-treatment serum active ghrelin levels according to our results (Table 2).

There were not any statistically meaningful changes in other laboratory findings.

We did not determine a significant correlation between changes in serum ghrelin levels $(\mathrm{ng} / \mathrm{ml})$ after two months of treatment as well as variation of BMI $(\mathrm{p}=0.941, \mathrm{r}=+0.017)$, BMI percentiles $(\mathrm{p}=0.344, \mathrm{r}=+0.212)$ and body weight $(\mathrm{p}=0.289$, $r=+0.237$ ) before and after the treatment. We did not observe an important correlation between OROS-methylphenidate dosage per kilograms and ghrelin variation values $(\mathrm{ng} / \mathrm{ml})(\mathrm{p}=0.580, \mathrm{r}=-0.125)$ after the treatment period. Difference of pretreatment and post-treatment OROSmethylphenidate dosages per kilograms also did not correlate with ghrelin variation $(\mathrm{p}=0.659$, $\mathrm{r}=-0.100$ ). In addition, we could not determine any significant correlation between changes in serum ghrelin level and variation of the Conners' rating scales subpoints reflecting severity of ADHD symptoms after e two months of methylphenidate treatment (Table 3). 


\section{DISCUSSION}

We did not observe a significant alteration in serum active ghrelin levels or in BMI and body weight parameters after 2 months of uninterrupted $18 \mathrm{mg}$ OROS-methylphenidate treatment in our sample.

Among brain regions involved in ghrelin's orexigenic effect, the most important is the hypothalamus, which has the highest density of ghrelin receptors (GHSRs). Extrahypothalamic sites like the ventral tegmental area (VTA) may also be important for relaying ghrelin's orexigenic effect $^{14}$. Ghrelin receptors have been detected not only in the hypothalamus but also in the hippocampus, substantia nigra, ventral tegmental area and raphe nucleus, brain areas that are known as being components of the brain reward pathways ${ }^{45-49}$. It has been also reported that drug craving and food hunger are similar in their psychological qualities and they are thought to share common underlying neural circuitries. Both of these are influenced by the mesolimbic brain reward system and its endorphinergic inputs ${ }^{50,51}$. It has been shown that ghrelin has a major role in the pathogenesis of alcohol dependence and craving which are closely related to the reward system ${ }^{52,53}$. Interestingly, people with ADHD have a greater risk for alcohol and other drug addiction. As a result in the future there should be studies trying to reveal if ghrelin plays a role in ADHD pathogenesis or is involved in substance abuse due to ADHD. Ghrelin also activates the orexin neurons in the paraventricular nucleus in the lateral hypothalamic area to express orexins which regulate arousal ${ }^{53,54}$. Modafinil, which is being used for the treatment of ADHD, narcolepsy and stimulant abuse, interacts with the orexins to stimulate alertness and wakefulness ${ }^{55,56}$.

Ghrelin is a potent modulator of the mesolimbic dopaminergic reward pathway. Ghrelin increases dopamine receptor D5 and acetylcholine receptor nAChR $\beta 2$ gene expression in the VTA and decreases expression of dopamine receptor genes D1, D3 and $\mathrm{D} 5$ and acetylcholine receptor gene $\mathrm{nAChR} \alpha 3$ in the nucleus accumbens ${ }^{28}$. Ghrelin increases ventral tegmental acetylcholine and increases dopamine release in the nucleus accumbens ${ }^{57}$. It is claimed that glutamate is required for ghrelin to stimulate the mesolimbic dopamine system rather than orexin or opioid signaling ${ }^{58}$. Methylphenidate also has a positive dopaminergic effect $\mathrm{t}^{1,2}$. Dysfunction in the cholinergic-dopaminergic reward system due to hyperghrelinemia is associated with addictive behaviors like compulsive overeating, alcohol use disorder and binge eating whether or not related to bulimia ${ }^{29,57}$. Ghrelin promotes the rewarding, hedonic aspects of eating independent from eating associated with body weight homeostasis ${ }^{54}$.

Ghrelin activity is associated with activity or the hippocampus and nucleus accumbens (NA). With that association ghrelin can affect other various reward behaviors in addition to food intake. Ghrelin augments hyperactivity and arousal due to cocaine, has antidepressant-like properties and is associated with greater alcohol consumption and craving $^{32,33,54,59,60}$. Cocaine is a stimulant agent like methylphenidate but, unlike methylphenidate, it is illegal and has neurotoxic and addictive properties. Systematic ghrelin sensitizes and ghrelin antagonists attenuate cocaine induced hyperlocomotion and ghrelin lowers the subthreshold of the psychogenic action of cocaine ${ }^{59,60}$ Central ghrelin activates arousal and wakefulness like stimulant medications in the treatment of narcolepsy and ADHD. The activation of the hypothalamic neural circuit including ghrelin, orexin and NPY neurons stimulates wakefulness, arousal, motor activity and may stimulate nocturnal and binge eating ${ }^{61}$.

Ghrelin increases GABA in the hypothalamus while psychostimulants decrease GABAergic transmission in the striatum ${ }^{13,62}$. Peripheral ghrelin increases noradrenaline in the arcuate nucleus, suggesting that ghrelin stimulates food intake at least in part through the noradrenergic pathway ${ }^{63}$. Methylphenidate has also a noradrenergic effect $^{64,65}$.

Perhaps one of the most important side effects of meyhylphenidate and other stimulants is growth and height retardation. Weight loss and reduced height velocity due to stimulant medication in 
ADHD is particularly observed in the first 6 months of treatment ${ }^{66}$.Poulton and Satterfield demonstrated that the growth rates for height and weight progressively normalized over 2 or 3 years of stimulant medication in $\mathrm{ADHD}^{66-68}$. Even in children on growth hormone therapy for severe growth failure, although methylphenidate has some negative effect on growth during the first years of treatment, the adult final height is not effected ${ }^{69}$.

Interestingly many years ago there was a presumption that the hyperactivity in ADHD would decrease the risk of obesity, but now it is known that obesity and ADHD have significant comorbidity ${ }^{70,71}$. It has been reported that children with ADHD have a greater risk for obesity in both epidemiological and clinical studies ${ }^{72}$. Holtkamp found a higher rate of obesity in untreated children with $\mathrm{ADHD}^{73}$. From a neuropsychological perspective, it has been suggested that ADHD and obesity result from cognitive, neuropsychological deficits like individual self-dysregulation, cognitive deficits, executive function deficits and dysfunctional motivational-reward systems and excessive goal directed motor activity. These failures are closely related to the dopamine and ghrelin system ${ }^{72,74}$ However, there have been studies not linking obesity in ADHD with neuropsychological, cognitive deficits. Lower socioeconomic status in ADHD may be related with obesity ${ }^{72}$.

Moreover, recent studies have showed that methylphenidate reduces overall energy intake with a selective reduction in dietary fat ${ }^{75}$. It is suggested that associated with attention problems, impulsivity and increased food consumption, the dopaminergic reward system and dopamine receptor genes might be the underlying mechanism of the comorbidity of ADHD and obesity in children $^{76,77}$. Perhaps ghrelin could be associated with ADHD and its relation with obesity. Low brain dopamine has been associated with overeating and obesity and agents increasing dopamine like stimulants reduce feeding behavior ${ }^{75}$.

It has been claimed that the greater prevalence of ADHD in obese children might be related to an imbalance in the dopaminergic reward system. Low ghrelin levels are associated with obesity ${ }^{78}$. In children, a substantial reduction in excess weight is accompanied with a progressive increase in serum levels of ghrelin ${ }^{79}$ and this increase can cause weight gain again. Ghrelin targets dopamine projections from the ventral tegmental area to the nucleus accumbens, it triggers increased dopamine neuronal activity in the VTA, leading to an increased dopamine turnover in the nucleus accumbens. ADHD symptoms have been reported to be related to a hypodopaminergic state and methyphenidate and other stimulants increase dopamine availability in the brain. The excitation of VTA dopaminergic neurons causes an increase in dopamine release in the nucleus accumbens, which in turns inhibit hyperactivity and inattentiveness. Since reducing excessive weight increases ghrelin levels, it has been hypothesized that reducing over the weight of obese children with ADHD might result in an improvement in ADHD symptoms ${ }^{80}$; although sufficient data is not available to support this suggestion.

It has been suggested that there is a relationship between the ghrelin increase before food restriction and drug-alcohol craving-seeking behavior. In the last few years there has been mounting evidence that ghrelin is related to psychostimulant drug addiction $^{30-33}$. In addition, ghrelin interacts with CART (Cocaine-and Amphetamine Regulated Transcript) peptides, which are known to be important in psychostimulant addiction / rewarding I reinforcing mechanisms ${ }^{81-83}$. CART is a neuropeptide released from the hypothalamus that transmits a physiological anorexic signal. Mutational screening of the CART gene in children with severe early onset obesity has identified a mutation, which is also linked to depression and anxiety. CART peptides can be the crucial point between obesity and mental health disorders and CART peptides may be significant in pathological eating behaviors associated with psychiatric drugs. CART peptides are also regulated by cocaine and amphetamine usage, which are psychostimulants like methylphenidate ${ }^{84}$. There must be further research on methylphenidate and its action on CART peptides. We do not have enough scientific knowledge and data to link an association between CART peptides, ghrelin and methylphenidate 
associated appetite decrease. Also there must be studies investigating the possible interaction between CART peptides, ghrelin, ADHD pathogenesis and ADHD induced substance abuse.

In our study on a prepubertal ADHD child group, methylphenidate significantly reduced ADHD symptoms and there was only a statistically meaningful positive change in height and unimportant alterations in body weight and BMI. We did not find significant differences in serum glucose, active ghrelin or in other metabolic and biochemical tests after two months of uninterrupted treatment. In light of these findings, we can suggest that methylphenidate is an effective and safe drug considering its effect on growth, supporting many past studies.

If methylphenidate's negative influence on appetite was directly connected with ghrelin and related mechanisms, we would have expected to see a decrease in serum ghrelin levels after methylphenidate treatment. If there was a meaningful weight loss in the group and if there was no relation between methylphenidate's mechanism on appetite decrease and ghrelin action, we might have expected to see an increase in serum ghrelin levels. According to our results and when considering ghrelin's physiological effect, our results are not consistent with both of these above hypotheses. These findings may be due to the insignificant body weight alteration and negligible appetite decrease in the sample group. Perhaps in future studies higher methylphenidate doses might make an alternation on serum ghrelin levels. Additionally, we couldn't determine any relation between ADHD symptom improvement and serum active ghrelin levels.

It has been hypothesized that increased ghrelin and decreased leptin signaling in the anorexia nervosa drive the activity of dopamine neurons in the ventral tegmental area. Increased ghrelin might be associated with hyperactivity, which is often seen in anorexia patients. In patients with anorexia nervosa, this altered activity of the dopamine system due to the increase of ghrelin may be involved not only in hyperactivity but also in aberrant cognitive processing related to food ${ }^{85}$. In response to acute physical exercise, plasma ghrelin levels tend to decrease $^{86}$. The decreased hyperactivity of children with successful treatment by methylphenidate in this study might have had an effect on ghrelin levels. This condition also makes it harder and more complicated to make a conclusion.

Even if ghrelin is involved in ADHD pathogenesis or methylphenidate has a direct effect on ghrelin action and on serum ghrelin levels, we may have not observed significant change in serum ghrelin levels because of all these complicated mechanisms we have summarized above.

Poulton et al. found that in the first 3 months of dexamethylphenidate etamine or methylphenidate treatment in children with ADHD, serum leptin and amino-terminal propeptide of type 1 collagen (P1NP) levels significantly decreased and albumin levels significantly increased. Although in the third year of psychostimulant medication the levels of P1NP, leptin and albumin normalized, the serum concentrations of osteocalcin, C-telopeptides (CTX), insulin like growth factor 1 (IGF-1) and insulin like growth factor binding protein-3 (IGFBP-3) significantly increased. In the third month and third year of the stimulant medication, they observed no significant changes in fasting levels of vitamin $\mathrm{D}$, parathyroid hormone (PTH), prealbumin, ferritin, transferrin, insulin, glucose or ghrelin like in our study ${ }^{66}$.

Previously Iseri et al. determined no significant change in serum insulin and leptin levels of boys with ADHD associated with methylphenidate treatment. There was no relation between BMI, appetite loss due to short acting methylphenidate and leptin-insulin levels ${ }^{87}$.

This study has some limitations such as relatively small sample size, lack of a control group and a relatively low methylphenidate dose especially for children near to puberty. In the future studies, the same or higher doses of methylphenidate for per kilogram should be used for the sample group. In the future, there should be studies about the stimulant action on ghrelin containing both sexes.

Ghrelin can be related to the metabolic effects of methylphenidate in children and ghrelin can be important in addiction-substance abuse 
mechanisms of children and adolescents with ADHD. Because of these factors, investigators should explore the possibility of ghrelin's involvement in ADHD pathogenesis or methylphenidate's action on ghrelin in future studies.

\section{References:}

1. Sengul C, Sengul CB, Kilic EO, Dilbaz N. Recent advances in the psychopharmacology of attention deficit hyperactivity disorder. Klinik Psikofarmakoloji Bulteni- Bulletin of Clinical Psychopharmacology 2005;15(4):192-7.

2. Greenhill LL, Pliszka S, Dulcan MK. Summary of the practice parameter for the use of stimulant medications in the treatment of children, adolescents and adults. J Am Acad Child Adolesc Psychiatry 2001;40(11):1352-55. [CrossRef]

3. Barkley RA, McMurray MB, Edlebdrock CS, Robbins K. Side effects of methylphenidate in children with ADHD; a systematic placebo controlled evaluation, Pediatrics 1990; 86(2):184-92.

4. Roche AF, Lipman RS, Overall JE, Hung W. The effects of stimulant medication on the growth of hyperkinetic children. Pediatrics 1979;63(6):847-50.

5. Spencer T, Biederman J, Wilens T. Growth deficits in children with attention deficit hyperactivity disorder. Pediatrics 1998;102(2 Pt 3):501-6.

6. Kuo DY, Hsu CT, Cheng JT. Role of hypothalamic Neuropeptide Y (NPY) in the change of feeding behaviour induced by repeated treatment of amphetamine. Life Sci 2001;70(3):243-51. [CrossRef]

7. Spencer TJ, Faraone SV, Biederman J, Lerner M, Cooper $\mathrm{KM}$, Zimmerman B, et al. Does prolonged therapy with a long-acting stimulant supress growth in children with ADHD? J Am Acad Child Adolesc Psychiatry 2006;45(5):52737. [CrossRef]

8. Kojima M, Hosoda H, Date Y, Nakazato M, Matsuo H, Kangawa K. Ghrelin is a growth-hormone-releasing acylated peptide from stomach. Nature 1999;402(6762):656-60. [CrossRef]

9. De Vriese C, Delporte C. Influence of ghrelin on food intake and energy homeostasis. Curr Opin Clin Nutr Metab Care 2007;10(5):615-9. [CrossRef]

10. Nakazato M, Murakami N, Date Y, Kojima M, Matsuo H, Kangawa $K$, et al. A role for ghrelin in the central regulation of feeding. Nature 2001;409(6817):194-8. [CrossRef]

11. Wren AM, Seal LJ, Cohen MA, Brynes AE, Frost GS, Murphy $\mathrm{KG}$, et al. Ghrelin enhances appetite and increases food intake in humans. J Clin Endocrinol Metab 2001;86(12):5992. [CrossRef]

12. Tschöp M, Smiley DL, Heiman ML. Ghrelin induces adiposity in rodents. Nature 2000;407(6806):908-13. [CrossRef]

\section{Acknowledgements}

This research was not supported by university funds or any drug company. The ghrelin kit material's expense was supplied by the first three researchers.

13. Cowley MA, Smith RG, Diano S, Tschöp M, Pronchuk N, Grove KL, et al. The distribution and mechanism of action of ghrelin in the CNS demonstrates a novel hypothalamic circuit regulating energy homeostasis. Neuron 2003;37(4):649-61. [CrossRef]

14. Steculorum SM, Bouret SG. Developmental effects of ghrelin Peptides 2011;32(11):2362-6. [CrossRef]

15. Cummings DE, Purnell JQ, Frayo RS, Schmidova K, Wisse $\mathrm{BE}$, Weigle DS. A preprandial rise in plasma ghrelin levels suggests a role in meal initiation in humans. Diabetes 2001;50(8):1714-9. [CrossRef]

16. Soriano-Guillen L, Barrios V, Campos-Barros A, Argente J. Ghrelin levels in obesity and anorexia nervosa: effect of weight reduction or recuperation. J Pediatr 2004;144(1):3642. [CrossRef]

17. Scott V, McDade DM, Luckman SM. Rapid changes in the sensitivity of arcuate nucleus neurons to central ghrelin in relation to feeding status. Physiol Behav 2007;90(1):180-5. [CrossRef]

18. de Lartigue G, Dimaline R, Varro A, Dockray GJ. Cocaineand amphetamine- regulated transcript: stimulation of expression in rat vagal afferent neurons by cholecystokinin and supression by ghrelin. J Neurosci 2007;27(11):2876-82. [CrossRef]

19. Andrews ZB, Erion D, Beiler R, Liu ZW, Abizaid A, Zigman J, et al. Ghrelin promotes and protects nigrostriatal dopamine function via a UCP2-dependent mitochondrial mechanism. J Neurosci 2009;29(45):14057-65. [CrossRef]

20. Hosojima H, Togo T, Odawara T, Hasegawa K, Miura S, Kato $\mathrm{Y}$, et al. Early effects of olanzapine on serum levels of ghrelin, adiponectin and leptin in patients with schizophrenia. J Psychopharmacol 2006;20(1):75-9. [CrossRef]

21. Togo T, Hasegawa K, Miura S, Hosojima H, Kojima $K$, Shoji M, et al. Serum ghrelin concentrations in patients receiving olanzapine or risperidone. Psychopharmacol (Berl) 2004;172(2):230-2. [CrossRef]

22. Murashita M, Inoue T, Kusumi I, Nagakawa S, Itoh $\mathrm{K}$, Tanaka T, et al. Glucose and lipid metabolism of long-term risperidone monotherapy in patients with schizophrenia. Psychiatry Clin Neurosci 2007;61(1);54-8. [CrossRef]

23. Sentissi O, Epelbaum J, Olie JP, Poirier MF. Leptin and ghrelin levels in patients with schizophrenia during different anti-psychotics treatment: a review. Schizophr Bull 2008;34(6):1189-99. [CrossRef] 
24. Jin H, Meyer J, Mudaliar S, Jeste DV. Impact of atypical antipsychotic therapy on leptin, ghrelin, and adinopectin. Schizophr Res 2008;100(1-3):70-85. [CrossRef]

25. Williams DL, Grill HJ, Cummings DE, Kaplan JM. Overfeedinginduced weight gain suppresses plasma ghrelin levels in rats. J Endocrinol Invest 2006;29(10):863-8. [CrossRef]

26. Palik E, Baranyi E, Melczer Z, Audikovszky M, Szöcs A, Winkler G, et al. Elevated serum acylated (biologically active) ghrelin and resistin levels associate with pregnancy-induced weight gain and insulin resistance. Diabetes Res Clin Pract 2007;76(3):351-7. [CrossRef]

27. Yang Y, Li W, Zhao J, Zhang H, Song X, Xiao B, et al. Association between ghrelin gene (GHRL) polymorphisms and clinical response to atypical antipsychotic drugs inHan Chinese schizophrenia patients. Behav Brain Funct 2012; 8:11. [CrossRef]

28. Skibicka KP, Hansson C, Egecioglu E, Dickson SL. Role of ghrelin in food reward: impact of ghrelin on sucrose selfadministration and mesolimbic dopamine and acetylcholine receptor gene expression. Addict Biol 2011;17(1):95-107. [CrossRef]

29. Jerlhag E, Egecioglu E, Landgren S, Salomé N, Heilig M, Moechars D et al. Requirement of central ghrelin signaling for alcohol reward. Proc Natl Acad Sci U S A2009;106(27):1131823. [CrossRef]

30. Wellman PJ, Hollas CN, Elliott AE. Systemic ghrelin sensitizes Cocaine-induced hyperlocomotion in rats. Regul Pept 2008;7;146(1-3):33-7.

31. Wellman PJ, Clifford PS, Rodriguez J, Hughes S, Eitan S, Brunel L, et al. Pharmacologic antagonism of ghrelin receptors attenuates development of nicotine induced locomotor sensitization in rats. Regul Pept 2011;172(1-3):7780. [CrossRef]

32. Yoon SJ, Pae CU, Lee H, Choi B, Kim TS, Lyoo IK, et al. Ghrelin precursor gene polymorphism and metamphetamine dependence in the Korean population. Neurosci Res 2005;53(4):391-5. [CrossRef]

33. Cummings DE, Naleid AM, Lattermann DPF. Ghrelin: a link between energy homeostasis and drug abuse? Addict Biol 2007;12(1):1-5. [CrossRef]

34. Goyette $\mathrm{CH}$, Conners $\mathrm{CK}$, Ulrich RF. Normative data on revised Conners' parent and teacher rating scales. J Abnorm Child Psychol 1978;6(2):221-36. [CrossRef]

35. Sener S, Dereboy C, Dereboy F, Sertcan Y. Conners' teacher rating scale Turkish version-1 Turk J Child Adolesc Ment Health 1995;2(3):131-141. (Turkish)

36. Dereboy C, Senol S, Sener S, Dereboy IF. Conners Anababa Derecelendirme Ölçeği uyarlama çalışması. X. Ulusal Psikoloji Kongresi Ozet Kitabi: Ankara 1998.

37. Conners CK, Sitarenios G, Parker JD, Epstein JN. The revised Conners' Parent Rating Scale (CPRS-R): factor structure, reliability, and criterion validity. J Abnorm Child Psychol 1998;26(4):257-68. [CrossRef]
38. Conners CK, Sitarenios G, Parker JD, Epstein JN. Revision and restandartization of the Conners' Teacher Rating Scale (CTRS-R): factor structure, reliability, and criterion validity. J Abnorm Child Psychol 1998;26(4):279-91. [CrossRef]

39. Kaufman J, Birmaher B, Brent D, Rao U, Flynn C, Moreci P, et al. Schedule for Affective Disorders and Schizophrenia for School Age Children-Present and Lifetime Version (K-SADSPL): initial reliability and validity data. J Am Acad Child Adolesc Psychiatry 1997;36(7):980-8. [CrossRef]

40. Gokler B, Unal F, Pehlivanturk B, Kultur EC, Akdemir D, Taner Y. Reliability and validity of Schedule for Affective Disorders and Schizophrenia for School Age ChildrenPresent and Lifetime version-Turkish version (K-SADSPL-T) Turk J Child Adolesc Ment Health 2004;11(3):109-16.

41. Wechsler D. WISC-R manual for the Wechsler Intelligence Scale for Children-Revised, New York: Published by Psychological Corporation; 1974.

42. Savasir I, Sahin N (editors). Wechsler Intelligence Scale for Children-Revised (WISC-R) Manual, Ankara: Türk Psikologlar Derneği Yayınları, 1995. (Turkish)

43. Neyzi O, Gunoz H, Furman A, Bundak R, Gokcay G, Darendeliler F, et al. Weight, height, head circumference and body mass index references for Turkish children. Turkish Pediatric Journal 2008;51(1):1-14.

44. Porstmann T, Kiessig ST. Enzyme immunoassay techniques. an overview. J Immunol Methods 1992;150(1):5-21. [CrossRef]

45. Guan XM, Yu H, Palyha OC, McKee KK, Feighner SD, Sirinatsingshi DJ, et al. Distribution of mRNA encoding the growth hormone secretogogue receptor in brain and peripheral tissues. Brain Res Mol Brain Res 1997;48(1):23-9. [CrossRef]

46. Shuto Y, Shibasaki T, Wada K, Parhor I, Kamegai J, Sugihara $\mathrm{H}$, et al. Generation of polyclonal antiserum against the growth hormon secretogogue receptor (GHS-R): evidence that the GHS-R exists in the hypothalamus, pituitary and stomach of rats. Life Sci 2001;68(9):991-6. [CrossRef]

47. Smith RG, Leonard R, Bailey AR, Palyha O, Feighner S, Tan $\mathrm{C}$, et al. Growth hormone secretagogue receptor family members and ligands. Endocrine 2001;14(1):9-14. [CrossRef]

48. Tannenbaum GS, Lapointe $M$, Beaudet A, Howard AD Expression of growth hormone secretagogue- receptors by growth hormone-releasing hormone neurons in the mediobasal hypothalamus. Endocrinology 1998;139(10):4420-3. [CrossRef]

49. Willesen MG, Kristensen P, Romer J. Co-localization of growth hormone secretagogue receptor and NPY mRNA in the arcuate nucleus of the rat. Neuroendocrinology 1999;70(5):306-16. [CrossRef]

50. Saper CB, Chou TC, Elmquist JK. The need to feed: homeostatic and hedonic control of eating. Neuron 2002;36(2):199-211. [CrossRef]

51. Wise RA.Drug activation of brain reward pathways. Drug Alcohol Depend 1998;51:13-22. [CrossRef] 
52. Kim DJ, Yoon SJ, Choi B, Kim TS, Woo YS, Kim W, et al. Increased fasting plasma ghrelin levels during alcohol abstinence. Alcohol Alcohol 2005;40(1):76-79. [CrossRef]

53. Toshinai K, Date Y, Murakami N, Shimada M, Mondal MS, Shimbara T, et al. Ghrelin-induced food intake is mediated via the orexin pathway. Endocrinology 2003;144(4):1506-12. [CrossRef]

54. Perello M, Sakata I, Birnbaum S, Chuang JC, OsborneLawrence S, Rovinsky SA, et al. Ghrelin increases the rewarding value of high-fat diet in an orexin-dependent manner. Biol Psychiatry 2010;67(9):880-6. [CrossRef]

55. Balles CA, Ewans DL, Dinges DF. Psychostimulants in psychiatry, amphetamine, methylphenidate and modafinil. In The American Psychiatric Publishing Textbook of Psychopharmacology, Schatzberg AF, Nemeroff CB (editors) $3^{\text {rd }}$ edition. Arlington VA: American Psychiatric Publishing; 2004. p. 671-84.

56. Simon P, Hémet C, Ramassamy C, Costentin J. Nonamphetaminic mechanism of stimulant locomotor effect of modafinil in mice. Eur Neuropsychopharmacol 1995;5(4):509-14. [CrossRef]

57. Jerlhag E, Janson AC, Waters S, Engel JA. Concomitant release of ventral tegmental acetylcholine and accumbal dopamine by ghrelin in rats. PLoS One 2012;7(11):e49557. [CrossRef]

58. Jerlhag E, Egecioglu E, Dickson SL, Engel JA. Glutamatergic regulation of ghrelin-induced activation of the mesolimbic dopamine system. Addict Biol 2011;16(1):82-91. [CrossRef]

59. Wellman PJ, Hollas CN, Elliott AE. Systemic ghrelin sensitizes cocaine-induced hyperlocomotion in rats. Regul Pept 2008;146(1-3):33-7. [CrossRef]

60. Jerlhag E, Egecioglu E, Dickson SL, Engel JA. Ghrelin receptor antagonism attenuates cocaine- and amphetamine-induced locomotor stimulation, accumbal dopamine release, and conditioned place preference. Psychopharmacol(Berl) 2010;211(4):415-22. [CrossRef]

61. Szentirmal E. Central but not systemic administration of ghrelin induces wakefulness in mice. PLoS One 2012;7(7):e41172. [CrossRef]

62. Centonze D, Picconi B, Baunez C, Borrelli E, Pisani A, Bernardi $G$, et al. Cocaine and amphetamine depress striatal GABAergic synaptic transmission through D2 dopamine receptors. Neuropsychopharmacology 2002;26(2):164-75. [CrossRef]

63. Date Y, Shimbara T, Koda S, Toshinai K, Ida T, Murakami $\mathrm{N}$, et al. Peripheral ghrelin transmits orexigenic signals through the noradrenergic pathway from the hindbrain to the hypothalamus. Cell Metab 2006;4(4):323-31. [CrossRef]

64. Rowe DL, Robinson PA, Gordon E. Stimulant drug action in ADHD: interference of neurophysiological mechanisms via quantitative modelling. Clin Neurophysiol 2005;116(2):32435. [CrossRef]

65. Yang L, Wang YE, Faraone SV. Association of norepinephrine transporter gene with methylphenidate response. J Am Acad Child Adolesc Psychiatry 2004;43(9):1154-8. [CrossRef]
66. Poulton A, Briody J, McCorquodale T, Melzer E, Herrmann M, Baur LA, et al. Weight loss on stimulant medication: how does it affect body composition and bone metabolism? - A prospective longitudinal study. Int J Pediatr Endocrinol 2012(1):30. [CrossRef]

67. Satterfield JH, Cantwell DP, Schell A, Blaschke T. Growth of hyperactive children treated with methylphenidate. Arc Gen Psychiatry 1979;36(2):212-7. [CrossRef]

68. Poulton A, Cowell CT. Slowing of growth in height and weight on stimulants: a characteristic pattern. J Paediatr Child Health 2003;39(3):180-5. [CrossRef]

69. Renes JS, de Ridder MA, Breukhoven PE, Lem AJ, HokkenKoelega AC. Methylphenidate and the response to growth hormone treatment in short children born small for gestational age. PLoS One 2012;7(12):e53164. [CrossRef]

70. Wilhelm C, Marx I, Konrad K, Willmes K, Holtkamp K, Vloet $\mathrm{T}$, et al.. Differential patterns of disordered eating in subjects with ADHD and overweight. World J Biol Psychiatry 2011;12 (Suppl.1):S118-S23.

71. Lam LT, Yang L. Overweight/obesity and attention deficit and hyperactivity disorder tendency among adolescents in China. Int J Obes (Lond) 2007;31(4):584-90.

72. Choudhry Z, Sengupta SM, Grizenko N, Harvey WJ, Fortier MÈ, Schmitz N, et al. Body weight and ADHD: examining the role of self-regulation. PLoS One 2013;8(1):e55351. [CrossRef]

73. Holtkamp K, Konrad K, Müller B, Heussen N, Herpertz S, Herpertz-Dahlmann B, et al. Overweight and obesity in children with attention-deficit/hyperactivity disorder. Int J Obes Relat Metab Disord 2004;28(5):685-9. [CrossRef]

74. Buss C, Entringer S, Davis EP, Hobel CJ, Swanson JM, Wadhwa PD, et al. Impaired executive function mediates the association between maternal pre-pregnancy body mass index and child ADHD symptoms. PLoS One 2012;7(6):e37758. [CrossRef]

75. Goldfield GS, Lorello C, Doucet E. Methylphenidate reduces energy intake in adults: a mechanism of reduced reinforcing value of food? Am J Clin Nutr 2007;86(2):308-15.

76. Liu LL, Li BM, Yang J, Wang YW. Does dopaminergic reward system contribute to explaining comorbidity obesity and ADHD? MedHypotheses 2008;70(6):1118-20. [CrossRef]

77. Campbell BC, Eisenberg D. Obesity, attention deficit hyperactivity disorder and the dopaminergic reward system. Coll Antropol 2007;31(1):33-8.

78. Zhu JF, Liang L, Zou CC, Fu JF. Plasma ghrelin levels and polymorphism of ghrelin gene in Chinese obese children and adolescents. Ir J Med Sci 2010;179(3):345-9. [CrossRef]

79. Kelishadi R, Hashemipour M, Mohammadifard N, Alikhassy $\mathrm{H}$, Adeli K. Short- and long-term relationships of serum ghrelin with changes in body composition and the metabolic syndrome in prepubescent obese children following two different weight loss programmes. Clin Endocrinol (Oxf) 2008;69(5):721-9. [CrossRef] 
80. Ghanizadeh A. Can body weight reduction in obese children improve attention deficit hyperactivity symptoms in the short term? clinical and research implications. Int J Endocrinol Metab 2011;9(1):278-9. [CrossRef]

81. Jaworski JN, Jones DC. The role of CART in the reward/ reinforcing properties of psychostimulants. Peptides 2006;27(8):1993-2004. [CrossRef]

82. VicenticA, Jones DC. The CART (cocaine-and amphetamineregulated transcript) system in appetite and drug addiction. J Pharmacol Exp Ther 2007;320(2):499-506. [CrossRef]

83. Douglas J, McKinzie AA, Couceyno P. PCR differential display identifies a rat brain mRNA that is transcriptionally regulated by cocaine and amphetamine. J Neurosci 1995;15(3 Pt 2):2471-81
84. Cheung WW, Mao P. Recent advances in obesity: genetics and beyond. ISRN Endocrinol 2012;2012:536905.

85. Adan RA, Hillebrand JJ, Danner UN, Cano AC, Kas MJ, Verhagen LA. Neurobiology driving hyperactivity in activitybased anorexia. Curr Top Behav Neurosci 2011;6:229-50. [CrossRef]

86. Shiiya T, Ueno $H$, Toshinai $K$, Kawagoe T, Naito S, Tobina $\mathrm{T}$, et al. Significant lowering of plasma ghrelin but not desacyl ghrelin in response to acute exercise in men. Endocr J 2011;58(5):335-42. [CrossRef]

87. Iseri E, Kilic BG, Senol S, Karabacak NI. Effects of methylphenidate on leptin and appetite in children with attention-deficit hyperactivity disorder: an open label trial. Methods Find Exp Clin Pharmacol 2007;29(1):47-52. [CrossRef] 